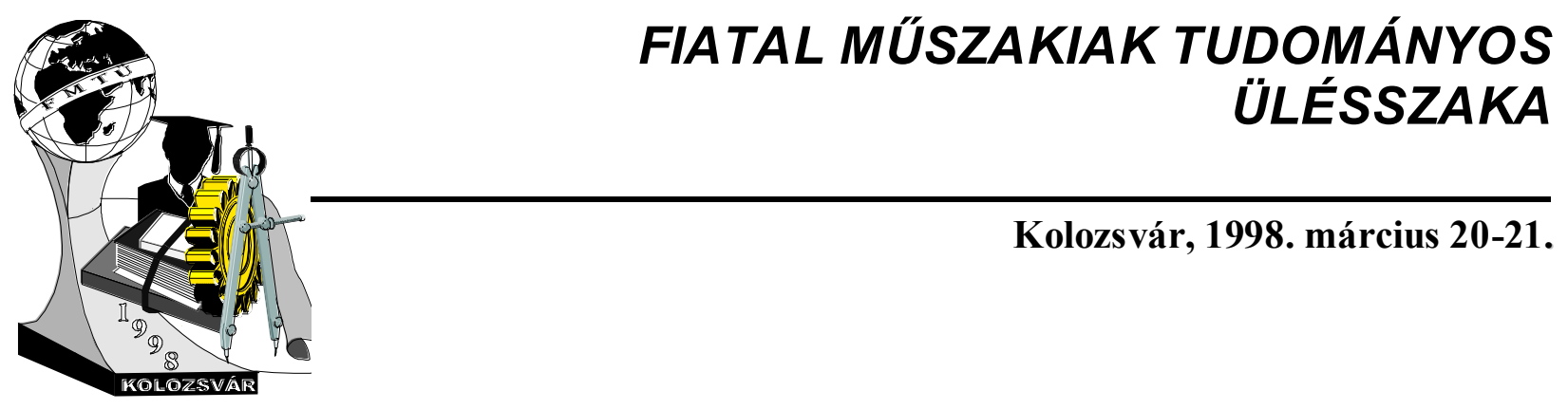

\title{
Számítógéppel segített alapanyag kombinálás a spirálgyártásban
}

\author{
Ormosi Viktor
}

\begin{abstract}
The first part of the presentation contains of the exposition of the raw-material-combining of the spiral manufacturing, the list of its types, the classification and modelling of individual processes. Then I propound the possibilities, functions and innovations of the developed combining-supporter program. The primary aspect of preparing the combining model was the classification. I propound the individual processes according to the distribution and assignment of technological parameters. Innovations are the systematization of these processes and the realization of a computer program supporting this system. The prepared technological model is the main frame of the program as well. This program provides a quick and interactive help for the completion and acquirement of the combining process. One of its advantages is that after data input the program offers the optimal combining theory, but it also provides an opportunity for the user to make his own choice. It gives a reliable and efficient help for the users, the dead time decreases, facilitates the secure data management and data storage. The individual workers can interfere with the procedures of the production process directly during their work on the production line by the help of this program. The core of this paper is that it provides such a modelling theory in the field of combining, which theory being supported by a computer program can accelerate these phases of the spiral manufacturing process.
\end{abstract}

\section{Bevezetés}

Az izzógyártás egyik része a spirálgyártás, valamint a spirálgyártás alapanyagaként szolgáló huzalok előállítása. A huzalgyártás két végterméke a volfrám és a molibdén huzal. A kombinálás a volfrám és molibdén huzalok párosítása oly módon, hogy a spirál ellenállása állandó értéken maradjon, függetlenül a huzalok névlegestől eltérő átmérő változásaitól.

A hajdúböszörményi gyár több üzemében folyó spirálgyártás közül a duplaspirál gyártás az, ahol jelenleg a kombinálást alkalmazzák. A duplaspirál gyártás lényege, hogy a raktárban rendelkezésünkre álló alapanyagokat két lépcsőben spiralizálják. Első lépés a volfrámszálaknak a primer molibdén huzalra történő rácsavarása, azaz a primer spirál előállítása. Ezután a megfelelő szekunder molibdén huzalra csavarják fel a primer spirált. A kész huzalokat csévékre tekerve tárolják és szállítják, innen darabolják tovább. A spirálgyártást és huzalgyártást összekapcsoló folyamatok egyik fontos lépése egyes esetekben a huzalok kombinálása. A spirálgyártási célra a legkisebb gyártási tétel (parti) összeállítása meghatározott 
elv szerint, valamint a huzalok párosítása oly módon, hogy az a végterméknek megfelelő technológiai paramétert eredményezzék.

A rendszer bemenő paraméterei a raktáron levő huzalok mért technológiai paraméterei, illetve azok az elöirt értékek, amelyeket a vevő által igényelt spirál adataiból nyerünk. A cél egy olyan modell elkészítése, amely a tudományos elméleteket és gyakorlati tapasztalatokat egy fedél alá hozva és a gazdasági paraméterek előtérbe helyezve a gyártó számára alternatívákat állít elő.

\section{Kidolgozott módszer ismertetése}

A spiralizálási folyamatok elve megegyezik mind a primer, mind a szekunder eljárásnál. A volfrám huzalt rácsévélik molibdén huzalra, ezt követően a kiválasztott másodlagos molibdénre az így előállt primer spirált ugyanazon technológiával felviszik. Ezt követi a spirál gyártásközi és egyéb technológiai minőség ellenőrzése, majd a gyártósorról kikerülve a molibdén magok vegyi úton való eltávolítása.

A kombináció lényege, hogy a huzal gyártóvonal által előállított volfrám és molibdén huzalok párosítják oly módon, hogy a huzalok névlegestől eltérő átmérö változásainak figyelembevételével a spirál ellenállása állandó értéken marad. A gyártási folyamat egyik alap filozófiája, ami rövidebb az legyen vékonyabb is. Részletesen kitérve a kombinálás lényegére, megfogalmazhatunk egy spirál ellenállás, súly különbség szintcsökkentő rendszert.

Kombinálás célja a spirál ellenállás változásának a minimalizálása. Ugyan előtérbe kerülhetne a spirál élettartama, mint meghatározó technológiai paraméter, de a rendszert az ellenállás változásának csökkentésére, mint alapfeltételre építették ki. Ezután ezen érték minimalizálására törekszünk. Az ellenállás-változás értékét meghatározó képlet.

$$
\Delta \mathrm{R} \% \cong-\mathbf{0 , 7} \cdot \Delta \mathrm{W}+\mathbf{0 , 3 5} \cdot \Delta \mathrm{MoI}+\mathbf{0 , 3 5} \cdot \Delta \mathrm{MoII}+[ \pm \mathbf{0 , 7} \cdot \Delta \text { Ford. szám }]
$$

A kombinálás biztosítani kell hogy a partikról kapott ellenállás értékek átlagértékét az egész termék átlag ellenállásától \pm 3\%-os eltérésen belül tartsuk. A termék gyárthatóságának elve, hogy a türésmezőt hat részre felosztva a türéshatárt rávetítjük a mért értékekre.

$$
\begin{gathered}
1<\mathrm{C}_{\mathrm{p}}=(\mathrm{T} / 6 \sigma) \\
\mathrm{C}_{\mathrm{pk}}=[(\mathrm{ATH}-\mathrm{X}) \mathrm{vagy}(\mathrm{FTH}-\mathrm{X})] / 3 \sigma
\end{gathered}
$$

Ahol: T : | alsó türéshatás - felső türéshatár $\mid ; \mathrm{X}$ : átlagérték; $\sigma$ : Szórás

\section{Megvalósított kombinálási elvek}

A következőkben a jelenleg létező és tisztázott elveket soroljuk fel:

\section{Egyenes kombinációs elv:}

Olyan huzal egyedeket csoportosítunk egy gyártási tételben, melyek csökkentik a volfrám huzal súlyeltéréséből adódó spirál hidegellenállás eltérését a névleges értéktől, azaz olyan huzalpárokat képezünk, melyek a türésmezőn belül azonos mérettartományba esnek. 


\section{Kétmezős egyenes kombinálási elv:}

Amikor a cséve beérkezik a spirálgyártás előkészítését megelőző raktárba rendelkezik egy bizonyos mért technológiai értékkel. Ezenkívül ez elöírt paraméterek elérése érdekében (amit a kész lámpa igényel) minden gyártmányhoz tartozik egy adott türéshatás. Ezen alsó és felső határok számtani közepéhez képest elfoglalt helyük alapján sorolhatók a csévék az egyes mezökbe. A középsúly bármelyik mezőben értelmezhető a huzalpártól függően. Amennyiben a molibdén és volfrám cséve ugyanazon határba esik egyenes kombinálásról beszélünk.

\section{Hárommezős egyenes kombinálási elv:}

Itt a türésmezőt értelemszerüen három részre osztjuk: Hárommezős kombináció alkalmazható abban az esetben, ha a fel nem használt huzalkészletek méreteltérése az egyharmad türésmezőt nem haladja meg, de nem azonos mezőbe esik és máshogy nem használható fel.

\section{Keresztkombinálás:}

Ha az egyik alapanyag egyik, másik pedig az ellentétes mezőbe esik keresztkombinálásról beszélünk.

\section{Vegyes kombinálás:}

Az első lépés az előzőhöz hasonlóan történik, tehát a molibdént egyenesen kombináljuk a volfrámmal, majd a gyártási és raktározási nehézségekből adódóan a nehézkes szekunder kombinálást elhagyjuk. Helyette a raktáron levő, és elérhető molibdén csévét választva kiszámoljuk a spirálgyártási paramétereit. Ezen fordulatszám értékeket a gépen közvetlenül beálltjuk, majd az új feltételekkel gyártunk.

\section{Nincs kombináció:}

A molibdén és volfrám huzalok a rájuk vonatkozó teljes türésmezőn belül összepárosíthatóak. Lehetőség szerint a nagyon szélső értékek párosítása elkerülendő. Szekunder mag párosítása primer spirálhoz, lehetőleg az egyenes kombinációs elv figyelembevételével történjen, és magpótlásnál az előző szál méretéhez igazodó méretű magot kell adni.

\section{Implementáció, müködés}

Az általam megírt programnak legfontosabb feladatai a technológiai müveletek elvégzése mellett az adatbázis-kezelés, felhasználóbarátságság és hogy interaktívan kezelhető felületet biztosítson. Ezek alapján esett a választás COMPUTER ASSOCIATES termékére a CA-VISUAL OBJECTS-re amely egymagában nyújt felhasználóközei környezetet, valamint adatbázis-kezelésre épülő CLIPPER alapú objektumorientált programozási felületet.

Megvalósítás lépéseit a következő néhány pontban lehet összefoglalni.

\section{- Kombinációs modell készítése}

\section{- Adatbázisok létrehozása}

Az egész adatbázis két fő adatstruktúrán alapszik, a dolgozók - valamint a huzal paraméterit tároló adattáblákon. A dolgozók adattábla adminisztratív, és program használhatóságát növelő célokat szolgál. 
A tényleges kombinálás a huzal adatbázisra épül, felhasználva azt az egyes kiválasztások és számítások elvégzésére.

\section{- Keretprogram készitése}

\section{- Modell bevitele a programba}

A főmenüben található kombináció részben fel vannak sorolva az előző pontokban ismertetett eljárások. Ezek közül választva megjelenik az aktuális problémát lekezelő ablak és végrehajtódik az adatmozgatás és az összes szükséges számítás. Ennek a feladatnak elvégzése érdekében meg kellet ismerni a huzalokról tárolt információk kapcsolatát. A következő ábra a primer kombinálás megvalósítását mutatja be a programon belül.

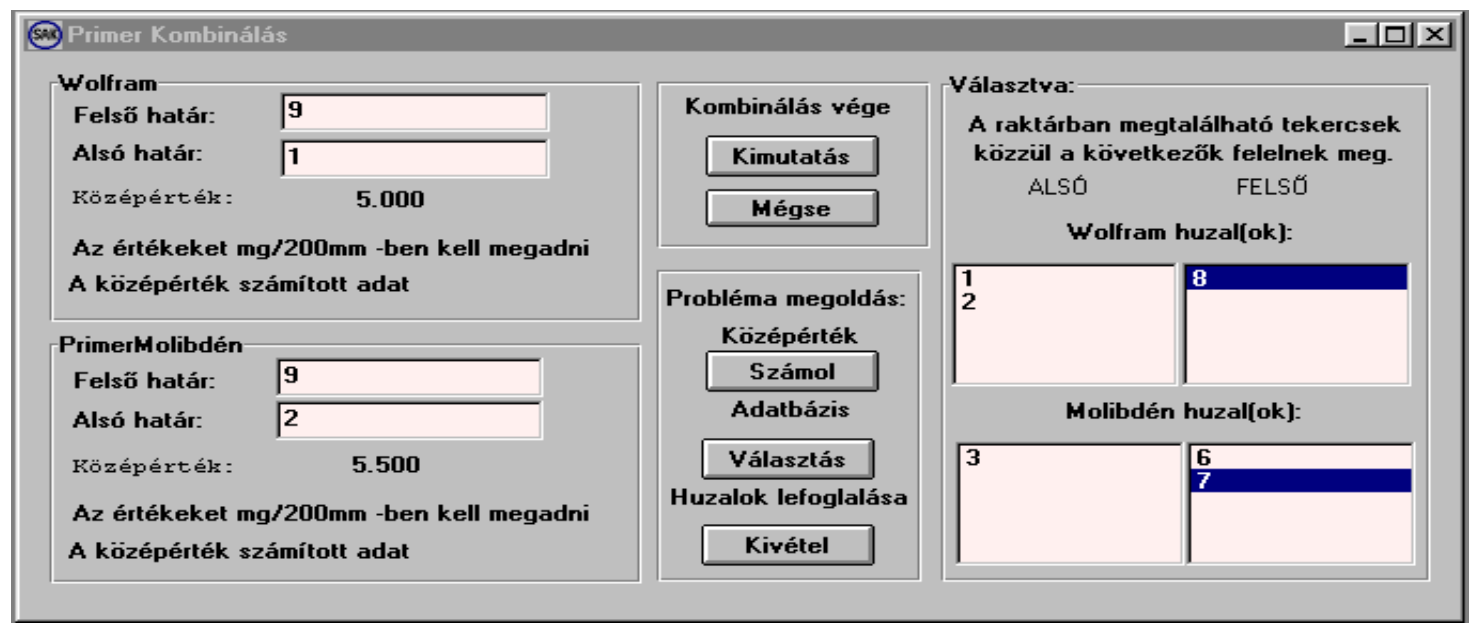

\section{- Rendszerterv}

A programmal szemben támasztott követelmények a következő funkcionális elemekben valósulnak meg:

- Jelszavas bejelentkezés

- Megfelelő menüszerkezet

- Adatbázisok kezelése

- Jelentés készítések

- A program geometriai szemléltetése

\section{Irodalomjegyzék}

[1]: dr. Nagy A., Pávay J., Oláh S: Számítógéppel segített huzalkombináció,

Wolfram kutatás és fejlesztés, 1995

[2]: Ormosi Viktor : Számítógépes programmal segített alapanyag kombinálás a spirágyárásba,

Diplomamunka, Mikolc 1997

\section{Ormosi Viktor}

Miskolci Egyetem, Általános Informatikai Tanszék

Miskolc Egyetemváros 3515 